\title{
Rural-urban migrants, translocal communities and the myth of return migration in Vanuatu: the case of Paama
}

Migrants vers la ville communautés translocales et le mythe du retour au

Vanuatu : le cas de Paama

\section{Kirstie Petrou and John Connell}

\section{OpenEdition \\ Journals}

Electronic version

URL: http://journals.openedition.org/jso/7696

DOI: $10.4000 /$ jso.7696

ISSN: $1760-7256$

Publisher

Société des océanistes

\section{Printed version}

Date of publication: 15 December 2017

Number of pages: 51-62

ISSN: 0300-953x

\section{Electronic reference}

Kirstie Petrou and John Connell, "Rural-urban migrants, translocal communities and the myth of return migration in Vanuatu: the case of Paama", Journal de la Société des Océanistes [Online], 144-145 2017, Online since 15 December 2019, connection on 15 March 2021. URL: http:// journals.openedition.org/jso/7696; DOl: https://doi.org/10.4000/jso.7696 


\section{Rural-urban migrants, translocal communities and the myth of return migration in Vanuatu: the case of Paama}

by

Kirstie PETROU* and John CONNELL ${ }^{* *}$

\begin{abstract}
Urbanization in Vanuatu has increased rapidly in recent decades. Circular mobility has gradually given way to urban permanence as second and third generations grow up in urban centres. Migrants from the small outer island of Paama are numerically significant in the capital Port Vila with more Paamese living there than in their 'home' island. Few have returned to Paama, despite a substantial proportion of all generations professing intentions to do so, 'one day', after other goals had been realised, while maintaining economic and social ties with island residents. Constraints to return included secure urban employment and housing, access to education and health services, the location of kin, fear of sorcery and intermarriage with people from other islands, while few welcomed the challenges of returning to more subsistence-oriented livelihoods and lifestyles. Those who had returned to Paama were mainly individuals with particular social status in island life, rather than people seeking to develop economic opportunities, on an island where employment and other economic activities are scarce, and carrying capacity limited.
\end{abstract}

KEYwORDs: urbanization, migration, return, Port Vila, Paama, livelihoods

Much of the Pacific is coming closer to the global situation where half the world's population live in urban areas. In recent decades, urbanization has proved seemingly inexorable especially in Melanesia as a consequence of internal migration and natural increase. Port Moresby, the capital of PNG is approaching 500,000 people and may well

\section{RÉSUMÉ}

Au Vanuatu, l'urbanisation sest développée rapidement au cours des dernières décennies. La migration circulaire a progressivement laissé la place à la sédentarisation urbaine, alors que deux voire trois générations de ni-Vanuatu grandissent en ville. Les migrants originaires de la petite île de Paama habitent en grand nombre à Port-Vila où on compte un plus grand nombre de Paamais que sur leur île d'origine. Peu d'entre eux retournent à Paama, même si une part importante de toutes les générations exprime le désir d'y retourner "un jour " une fois ses projets réalisés et maintient des liens économiques et sociaux avec les résidents de l'île. Parmi les raisons qui jouent contre le retour vers Pamaa se trouvent la sécurité du travail et du logement en ville, l'accès à l'éducation et aux services de santé, la présence de la famille, la peur de la sorcellerie et les mariages inter-ethniques. Peu senthousiasment par rapport aux défis liés à l'économie de subsistance et à la vie rurale. Ceux qui y sont retournés, face à l'emploi et aux activités économiques rares, aux ressources limitées, sont plutôt ceux qui y jouissaient d'un statut social particulier, que des gens cherchant à y développer l'économie locale.

MoTs-ClÉs : urbanisation, migration, retour, Port Vila, Paama, moyens de subsistance

become the first millionaire city in the Pacific by 2030. The population of Port Vila, the capital of Vanuatu, has passed 50,000 and spilled over from its formal urban boundaries into rural Efate. Rapid urbanization has created multiple challenges, especially as it increasingly appears that urban residents are becoming more permanent and more re-

* School of Geosciences, The University of Sydney, kirstie.petrou@utas.edu.au

** School of Geosciences, The University of Sydney, john.connell@sydney.edu.au 
luctant to return 'home' and consequently require urban service provision. This paper seeks to examine the extent to which migrants from the small outer island of Paama have become permanent urban residents, committed to remaining in the city, or, by contrast, anticipating a return home as part of a persistent pattern of circular migration.

Throughout much of the Pacific, mobility to urban areas has historically been dominated by short term or temporary moves, a pattern often reinforced by colonial policy. In Melanesia, despite this long, well documented history of short-term, transient, circular mobility, in Vanuatu as much as elsewhere (e.g. Bedford, 1973; Bonnemaison, 1976; Bastin, 1985; Chapman and Prothero, 1985), a trend towards urban permanence, dating back to at least the 1960s, has also emerged (e.g. Tonkinson, 1979; Haberkorn, 1987; Mecartney, 2001). Rural migrants can no longer be considered temporary sojourners and expected eventually to return to their 'real' homes. Circular migration appears to be disappearing. Nonetheless, governments continue to argue that issues relating to increasing urban populations, including lack of suitable housing, high unemployment rates, environmental degradation, discontent and increasingly visible poverty, could be solved if migrants returned to their 'home' villages, so resulting in the lack of adequate urban management, and the will to undertake it (Connell, 2011; Mecartney and Connell, 2017). Versions of this discourse are often echoed by migrants themselves, many of whom claim - publicly at least - that they will one day return to the supposedly idyllic rural lifestyle offered by outer islands. However little detailed research exists on whether return migration occurs, so perpetuating early notions of circular mobility. Using a case study of rural-urban migrants from the island of Paama, this paper investigates whether claims to eventual return to rural areas are carried through. In doing so, it considers both the barriers faced by, and attitudes of urban migrants to return, and the experiences of the few Paamese who have made the return journey 'home'. The paper further asks whether there are particular groups of people who are most likely to engage in return migration, and what are their motivations. The following section considers existing research into return migration, drawing on examples from the Pacific region, that incidentally highlight the lack of contemporary studies in Melanesia. A discussion of data collection follows, and a brief history of migration in Vanuatu is presented to contextualise the present study. Return migration is then defined, before the experiences and views of urban migrants, returnees and rural residents are discussed. The paper concludes that despite enduring discourses of return, actual return migration remains minimal, and attempts to encourage this mobility may not necessarily be in the best interests of migrants or urban communities.

\section{Return migration: a review of the literature}

The rhetoric of return migration is common throughout the Pacific, however actual return remains rare, and it is difficult to identify both the kinds of migrant most likely to return, and any typical motivations for return. Given the diversity of Pacific migration contexts that is unsurprising. Thus in the village of Nukunuku (Tonga), relatively close to the national capital, where employment and commercial opportunities existed, return migrants were diverse in terms of age, sex and level of education. While a variety of factors influenced the decision to return, family reasons ranked highly, and returnees tended to be economically successful. Many of those who did return however, did not plan to stay indefinitely (Maron and Connell, 2008). By contrast, skilled health workers returning to Fiji, Samoa and Tonga were 'unlikely' to cite economic reasons as a consideration for their return, and perceived return as a primarily social rather than economic phenomenon, linked to family circumstances. However, all had options of taking up good employment at home, but many of them too did not expect to remain at home permanently, and remigration was considered a real possibility (Connell, 2009). In both these contexts migrants were returning from overseas to locations where good job opportunities and welfare provisions existed. By contrast for many long-term migrants, concerns over adapting back to home societies (Muliaina, 2003), and a reluctance to abandon second generation children in destination areas (Macpherson, 1985) proved brakes on return. However the fragmentary data that exist suggest that, as in Nukunuku, migrants are quite diverse and return for a range of reasons, reflecting their own household circumstances and socio-economic contexts in different places, and that return is rarely regarded as final.

Comparable studies of return migration in Melanesia are largely absent. Although both Dalsgaard (2013) and Rasmussen (2015) state that many migrants from different parts of Manus (Papua New Guinea) return home to retire, a similar perspective to that expressed much earlier for Papua New Guinea as a whole (Curtain, 1980), there are only limited indications that return at retirement does occur. Writing about Kragur (Papua New Guinea), Smith (2002, 2013) briefly notes that return migrants may have difficulty in adjusting to island life, and that conflicts sometimes occurred between the 'urban' worldviews of migrants and that of their rural kin. Similarly, Gewertz and Errington (1999) record that return migrants in Chambri (Papua New Guinea Sepik) may be perceived as troublemakers by rural villagers. Beyond issues of reintegration, migrants face various barriers to return, which vary with context. The poorest migrants, who have been 
unable to maintain exchange relationships with rural areas, are often the least likely to feel able to return 'home' (Curry and Koczberski, 1999; Dalsgaard, 2013). Migrants may marry partners from other language groups who are similarly unfamiliar with local contexts. In Bougainville a significant constraint to return was marriage to someone from a different cultural and language group (Connell, 1988). While data on remittances in Melanesia are scarce the limited number of studies do suggest that in almost all contexts migrants send remittances both as a means of supporting the livelihoods of those at home and providing social insurance against their own probable or possible return home, as part of a moral economy. Remittances are often highest when a migrant intends to return home however financial ability to remit also plays a role. Nonetheless, remittances alone are not necessarily a reliable indicator of return migration, and reduced remittance levels over time do not always reflect a waning commitment to home, but may result from changing family structures (Brown and Connell, 2015). Return migration may be constrained by reluctance to abandon second-generation children who may lack the linguistic skills and social knowledge to 'return' to increasingly unfamiliar places (Macpherson, 1985). Others may be reluctant to return to places where infrastructure (such as electricity and running water) is absent or sporadic, access to services is limited and economic and employment opportunities scarce. Despite a widespread discourse of urban impermanence and return, actual return 'home' is neither easy nor feasible. Quite simply contexts vary enormously hence definitive conclusions are absent.

Much of the research addressing urban-rural return migration in the Pacific is now much more than a decade old. While these studies provide useful insights into trends in return migration, most date from an era where national populations were smaller, urban populations were less well established, urban employment opportunities seemed greater yet circular migration remained normative, and, in some cases, a new era of self-determination resulted in political optimism. How rural-urban return migration manifests in contemporary $\mathrm{Me}$ lanesia remains largely unexplored, and it is this question that this paper seeks to explore.

\section{Data collection}

Fieldwork for this research took place during March-November 2011. Kirstie spent three months on the island of Paama working in the villages of Liro, Liro Nesa, Asuas and Voravor and used a census style approach to interview at least one adult from every Paamese household (108 interviews across 90 households).
Interviews were semi-structured and focused on experiences of and attitudes towards mobility. Interview data were augmented by participant observation which allowed for comparison of how villagers spoke about migration, with how they practiced it. Furthermore, this approach enabled observation and comparison of return migrants and non-migrants, and how they functioned within the wider community. From Paama, Kirstie travelled to Port Vila, spending roughly five months working with the urban Paamese community (106 interviews across 74 households, comprising 60 first and 46 second generation migrant households). Migrants and their families were identified with the help of three gatekeepers, male and female and of varying social status, each of whom facilitated access to a different subset of the urban Paamese population. Urban Paamese were asked about their own mobility histories and future mobility intentions, including their attitudes towards and plans for return to Paama. To contextualise this information, interviews also covered the practicalities of urban life including migrants' education and employment. Fieldwork was conducted entirely in Bislama, Vanuatu's lingua franca.

\section{Setting}

Vanuatu is located in the southwest Pacific, and comprises roughly 80 islands, approximately 65 of which are home to the nation's small population of 234,000 (Vanuatu National Statistics Office, 2011) (fig. 1). Governed by a AngloFrench Condominium arrangement from 19061980 , the nation's capital, Port Vila, was initially established as a colonial administrative centre in the late 1800 s. During the early colonial era, niVanuatu presence in town was tightly controlled, and those who did not hold employment, or were not indigenous to Efate, were returned to their home island after a period of 15 days. NiVanuatu holding urban work permits were subject to strict curfews, and, under the threat of discipline, were expected to vacate the urban centre by $9 \mathrm{pm}$. Temporary urban residence was reinforced by wages, accommodation and employment types that catered to single males. Furthermore, Port Vila was considered an inappropriate place for women, and both ni-Vanuatu and colonial women were rarely present in town (Haberkorn, 1987). Chapman and Prothero (1983) suggest that ni-Vanuatu readily accepted these mobility restrictions as they were largely consistent with traditional patterns of mobility which, for males at least, were commonly structured around circulation with an expected return to home places, which themselves were closely linked to identity. 


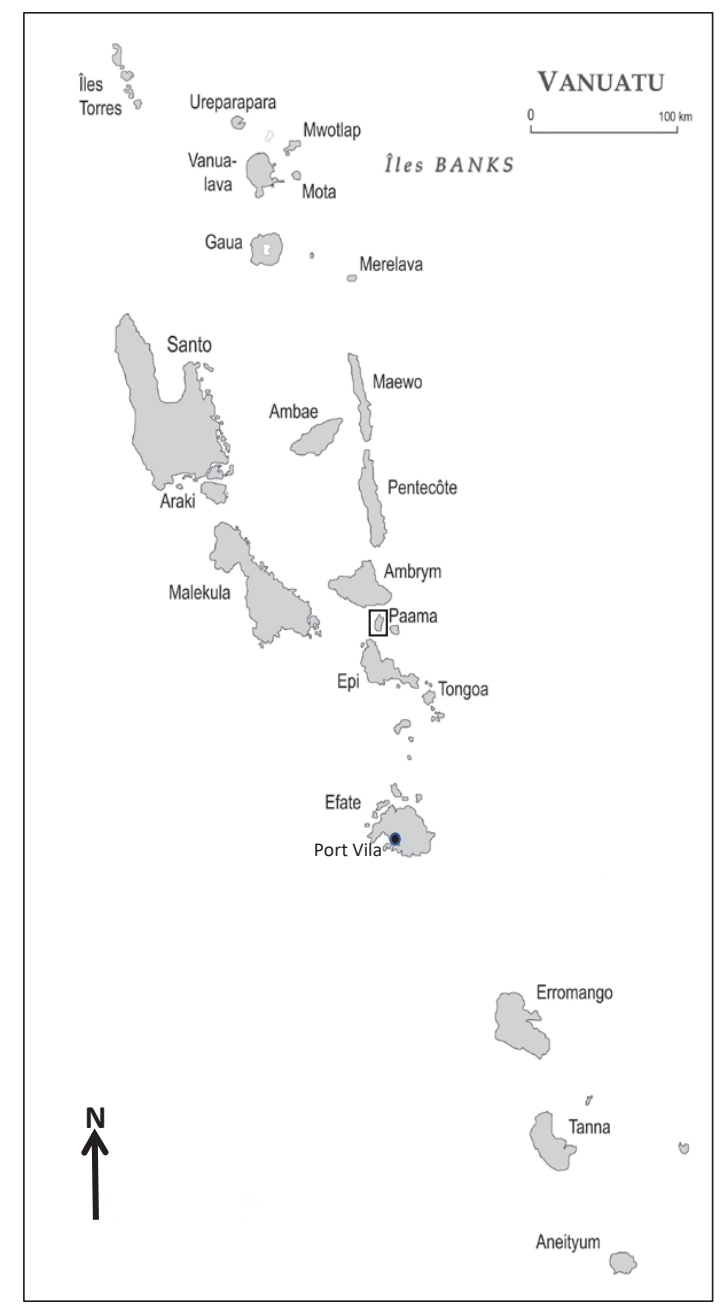

Figure 1. - Map of Vanuatu showing Paama and Port Vila (adapted from Lacito, 2003)

Port Vila remained small until World War Two, when the United States military made a massive investment in infrastructure. Labour requirements were such that most male ni-Vanuatu were employed by the military at some point, and for many, this provided a first experience of urban life (Bedford, 1973; Haberkorn, 1987).

From the 1960s onwards, the concentration of services in Port Vila influenced moves for education, healthcare and employment. Much of this urban growth was linked to migration, which had a primarily economic rationale, as people sought the 'fast money' of urban wages, alongside access to services, and a perceived future for their children. Women began moving in greater numbers due to increased educational levels and employment opportunities, familiarity with urban life, and large kin networks able to chaperone and assist new arrivals. These kin networks in turn led to increased rural-urban mobility through the dissemination of information regarding work and other opportunities (Haberkorn, 1987). Males continued to dominate mobility streams however, and during the 1970s, many migrants remained rurally oriented. Circular migration persisted well into the 1980s for some island groups (Bedford, 1973; Bonnemaison, 1976; Bastin, 1985). For others however, town gradually became a 'home' of sorts, and although the discourse of an eventual return to island 'homes' persisted, the trend towards long term urban residence was evident (Tonkinson, 1979; Haberkorn, 1987; Philibert, 1994; Mecartney, 2001; Chung and Hill, 2002). Port Vila continued to grow and at the last census (2009) its population was 44,040 , having doubled in size from 29,356, a decade earlier. Demographic trends suggest that is has now passed 50,000 people, with a further significant urban population beyond the formal urban boundary. By 2009 , the population of Port Vila constituted $19 \%$ of the country's total population, and it now holds over a quarter of the national population (Vanuatu National Statistics Office, 2011).

While migration is often seen to be the main cause of urban growth, and is certainly significant in Melanesia, natural increase is becoming more important. Birth rates are high, with the Total Fertility Rate of 4.1 being one of the highest in the Pacific. Urban fertility means that Port Vila is increasingly the home of second, third and later generations. Such people 'belong' to the city, have often experienced nothing else and are not migrants with another 'home' to which they might return if urban life does not work out. Indeed, some urban residents acquire good jobs, others marry across language and island boundaries and find it convenient to stay in the 'neutral' city. Towns and cities are their homes, old ideas of circular migration are disappearing.

In recent years, little has been written about ni-Vanuatu mobility, however the trend towards long term urban residence appears to be continuing, and this, along with the evolution of the urban social environment, has been the subject of a number of studies (eg. Philibert, 1988, 1994; Mecartney, 2001; Mitchell 2002, 2004, 2011; Kraemer, 2013). Eriksen (2008) has suggested that urban permanence is directly related to increases in the urban female population which, she argues, has facilitated the establishment of families in town. Lindstrom (2011) noted that, in most cases, relocation of migrants from Tanna to Port Vila was permanent. Furthermore, rather than trying to entice urban migrants 'home' to rural islands, the Tannese community focused on maintaining rural-urban kinship bonds, and a constant flow of visitors travelled between the village and town. These trends are correlated by 2009 census data which indicated that roughly two thirds $(67 \%)$ of Vanuatu's urban population had lived in town for at least five years (Vanuatu National Statistics Office, 2011), significantly longer than is commonly associated with tem- 
porary migrants (Bedford, 1973; Haberkorn, 1987). It is thus reasonable to assert that return migration may well be minimal, however little detailed evidence exists to confirm or deny this hypothesis. This research thus aims to provide insight into patterns of return mobility and the implications that these may carry, a topic about which little has been written.

\section{Paama}

Paama is a small, mountainous outer island located to the north of Efate. Measuring approximately $4 \mathrm{~km}$ by $9 \mathrm{~km}$, Paama is linked to Port Vila by a twice weekly flight, and to neighbouring islands by various irregular ships. Liro, the island's 'capital', and the setting for much of this research, is home to the island's council chambers and bank, as well as a school, health centre, and various small stores. Households universally engage in subsistence agriculture as a significant livelihood practice. The majority of households do not have a regular income earner, and those with rural employment usually earn wages that are small and sporadic. Absent kin provide an important means of economic support through remittances, as well as providing social support through disseminating information about urban life and opportunities for urban work. Paamese have a long history of migration away from the island (Haberkorn, 1987), and of the 4,977 niVanuatu who identify as Paamese, only 1,544 reside on Paama. Despite the island's small size, Paamese represent one of the largest migrant groups in Port Vila, and are a well-established urban community (Vanuatu National Statistics Office, 2011). The Paamese demographic balance has firmly shifted to town.

\section{Return migrants}

For Paamese, mobility has long been part of life (see also Haberkorn, 1987; Lind, 2014). In 2011 only $14 \%$ of rural Paamese had never lived or worked away from their home island for an extended period. Moreover, due to the location of health and other essential services, even they had made short trips away from Paama. Such absences were so common as to be considered insignificant. This research draws upon this system of self-classification when identifying return migrants, with return migrants defined as those who, during their absence from the island, had an established primary place of residence that was not Paama. Thus, those who spend extended periods (sometimes up to two years or more) 'visiting' off-island kin are not conside- red return migrants. Nor are those - generally older males - who may have spent many years engaging in circular labour migration considered returnees, as in both of these examples the migrant, as well as the wider Paamese community, would classify themselves as temporarily absent. In most cases therefore, return migrants did not have an established household on Paama during their absence, although all held customary land that was often left in the care of rural kin, and some may have built a rural house, or begun to accrue materials for this purpose.

\section{Attitudes to return amongst urban migrants}

As is common throughout Melanesia (Curtain, 1980; Strathern, 1985; Curry and Koczberski, 1998; Eriksen, 2008), a strong rhetoric of return exists amongst urban Paamese: roughly half $(49 \%)$ of all migrants stated that they would ideally like to live on Paama again one day, but 'one day' was never regarded as being imminent. The desire to return to Paama reflected the belief that life on the island was easier, particularly in terms of access to food, one of the major and most resented expenses associated with living in Vila. In reality however, there were a number of barriers that made it difficult for migrants to return home. Significantly, many of the reasons migrants provided for staying in town differed from those for initial migration, which mostly centred around economic needs and family benefits.

Women were more ambivalent about return than men. This can be attributed to their reliance on (Paamese) husbands for land access on the island, and the relatively limited number of roles available for women on the island beyond that of mama (mother): a church attending island dress wearing mother, who is expected to complete the bulk of everyday (house)work. Women aged 1524 years were the least likely to plan on returning, consistent with the lack of young women in this age group resident on the island. Those aged 2544 years were the most likely to want to return to Paama, as this was the period where more demanding child care was generally needed. There was a decline in the expectation to return in women aged 45 years and over, as by then many were well established in Vila, and the social and economic costs of return were considered too high.

Only males aged 45 years and above were clearly more oriented towards return than staying, reflecting the ideal of retirement to the island. However children often preferred that parents 'retire' in Vila.

"[My father] wasn't pleased [to come and live in Vila]. But we had to bring him here [...] when my mother died, there wasn't anyone on Paama to look after him. So we told him that he didn't have a choice 
and he had to come and live with us because he wasn't strong enough to make a garden by himself. And we thought that he should come and live with us so that we could look after him until he [dies.] All of us brothers live here and we work, so it wouldn't be right for him to live by himself and us to all live here. We would live well, but he wouldn't, he would suffer, so that's why we decided that he had to come." (Male, 41 years)

Somewhat predictably, more first than second-generation migrants claimed that they would one day return to Paama, partly because of their superior access to island housing. Nonetheless, only half of all second-generation migrants categorically stated that they would not live on Paama in the future.

Marriage between Paamese and people from elsewhere in Vanuatu has steadily increased from the 1980s onwards. In 1983, $80 \%$ of Paamese men had married women of Paamese origin (Haberkorn, 1987). By contrast, in 2011 almost half $(48 \%)$ of all partnered Paamese aged 25 years or older were in a 'mixed' relationship. As would be expected, second-generation migrants contracted more marriages to non-Paamese spouses, accounting for 39\% and 66\% of first and second-generation partnerships respectively. 'Mixed' relationships were often initiated in town, reflecting the wider population from which spouses could be chosen, and a desire for relationships based on 'love' rather than kastom (traditional) arrangements. For couples married to partners from a different island, town provided a 'neutral' place of residence, where both partners had continued access to wantok (language group) networks, and were thus less socially isolated. Furthermore, like Ambrymese (Eriksen, 2008), some migrants in mixed marriages were wary of relocating to an unknown rural area for fear of nakaimas (black magic/sorcery). For others, issues including the complicated land claims sometimes associated with inter-island marriage (Connell, 1988) provided practical barriers to relocation. Inter-island marriages amongst Paamese urban residents reinforced commitment to town.

"Sometimes, when men marry a woman from another island, they just base themselves in Vila. When they marry a Paamese woman, they go to Paama." (Male, age unknown)

Attitudes to return were largely independent of length of urban residence. Nonetheless, for long term urban migrants real practical limitations existed when it came to reclaiming land that was nominally theirs, yet had been utilised by kin for an extended period. Many such migrants were simply unsure of their ability to access this land, and by extension, where they would live or how they would support themselves on an island where subsistence agriculture represented the main livelihood strategy.
"Yes, I have [land on the island]. But, I say I have some, but I'm not sure if... The land is there, I know I have it, but our [classificatory] big brother has built his house on it." (Male, 35 years)

Similarly, buying land and/or building a permanent house in town were commonly interpreted as signs of urban permanence. Thus, when Paamese spoke of those who had bought land in Vila, they often used the phrase finis nao (that's it, it's over) to imply that a return to the island would not occur.

Likewise, as physically engaging with the land via subsistence activities reinforced the relationship between person and place, so garden metaphors, referring to the traditional connection with one's land were commonly employed by urban migrants to express detachment from the island, and anticipated difficulties entering a social environment with many unknowns. While some second-generation migrants confided that they had not learned certain aspects of rural life such as gardening, they generally believed that they could learn when (if) they moved to the island.

"I think just because I have lived in Vila for a long time now, in town, if you were to go back to the island you would find it hard ... For example, lots of us who live here don't make gardens. So if you went to the island you would have to make a garden, and you would say how do I make a garden? Once I went with some other Paamese boys to the other side of Efate. We went to plant manioc and yams, so some of us planted manioc, and some planted yams. I was planting yams, and when I finished, I had a look around and saw some of the manioc cuttings had been planted upside down. If you were to go to the island and make a garden like this, you'd have to wait, I don't know how many months, but your manioc would never grow." (Male, 37 years)

Youth were rather more likely to perceive urban life as their own way of life and not as 'an alien interlude' (Morauta and Ryan, 1982).

Holding employment in Vila provided a further barrier to return, and prevented other kinds of mobility, such as seasonal work, that necessitated lengthy absences and could result in the loss of jobs. However, even where work was a factor in deterring mobility, the location of close family members played an important role in return (see below), and urban residence itself remained independent of employment types and duration.

For others, fear of nakaimas on the island proved a significant barrier to return. These fears were often linked to the unknown aspects of rural life that arose after extended periods of urban residence.

"I'm scared to go and stay on the island. I've lived in town a long time and I'm scared to go back to the island again. I went in 1998 and only stayed for two 
weeks, then I came back here. Because I'm scared of nakaimas." (Female, 35 years)

In general, migrants maintained much stronger ties with the island when they had close family (most commonly parents, children or siblings) living on Paama, and return was often dependant on the location of family members.

"Before, I just stayed on the island, but all of my family travelled and came [to Vila]. But I stayed with my mother [on Paama]. But when she died, I left. Yes, I left and I came here, and I have stayed. Sometimes I think about going [to Paama], but I think if I do go, who would I be going to visit? If my mother was alive, I would go and visit her. But it's better if I just stay here ... I have never been back to visit." (Male, 50 years)

For many, the large, well-established urban kin network made it possible to participate in the Paamese community without returning to Paama; the same life cycle events were commonly observed in both locations, and linguistic and emotional contact did not require mobility as it had during the years of circular migration. The use of Paamese place names in Port Vila, for example 'Seaside Seneali', further aided in fostering continuity with rural areas and a sense of 'home' in the urban environment (Eriksen, 2008; Lind, 2014). Thus, when asked about his contact with the island, one older man stated that Vila was just like Paama - he lived in a quiet area in a community environment. This along with the demographic shift towards urban areas meant that many Paamese had more relatives living in town than on Paama. They therefore did not need to return 'home', to feel at home.

Finally, urban residents placed considerable emphasis on setting themselves up to survive comfortably before any return to Paama could be considered. Some migrants who owned urban land wanted to build rental properties to secure a steady income stream, should they return to Paama, while others planned to start a store or other small business on the island. Those with school aged children wanted to wait until their children were married and employed, so that they could receive remittances when on Paama. Urban Paamese were therefore working towards various goals, many that would take time, before a return 'home' could be considered, so explaining the difficulty in attaching a date to plans to return. However, as for transnational Caribbean migrants (Olwig, 2007) the longer migrants stayed away, the harder it became to realistically contemplate a return. While it was rarely admitted in public (see also Macpherson, 1985), those who had spent most or all of their lives in Vila recognised that a return to the island would be difficult at best, and some felt they had nowhere else to go.
"The two of us can't go to the island anymore. If we were to go, it would be hard work for us to set up our family there. So we just stay here, and we have bought land here." (Male, elderly)

"I should say that I will go back to the island, but it would be a little bit hard for me now, because I have spent almost my entire life in town. I think it's the same for those who live on the island when they come to town, because they have spent their whole life on the island. I think they would only be able to stay in town for a day or two before they wanted to go back to Paama. They wouldn't feel right in town. Because, I think the cost of living in town is too high, and it makes it difficult for those who live on the island to come and live in Vila. Us too, I think we would find it a bit difficult to go and live on Paama because they don't have all of the things we are used to there. You would have to start saving a lot of money again because you would need to start over and build a house and everything." (Male, 59 years)

"Vila is my home now. Whether I like it or not, I stay. I just stay, because where would I go? It is my home now because I don't have anywhere else I could go." (Female, 56 years)

Some migrants therefore felt themselves to be 'stuck' in Vila, and for these Paamese, urban permanence had simply emerged as an inadvertent outcome of long-term urban residence. Beyond that, for some urban residents at least, Vila was the preferred place of residence; 'home' was no longer on the island. For others however, it was not a straightforward decision, and they struggled with feelings of where they would like to live versus the structural constraints experienced on the island.

"Yes, I like Vila, I think because I have been here a long time now, and I have become used to life in Vila. I have made my living and I am based in Vila, so I like it. Because when I go to the island, I stay for a while and then I feel like I want to come back to Vila, I am glad when I know I'm coming back. I think because it is my home. I have made my home here and I am glad of it." (Male, 53 years)

"I don't like it here. I just stay because of work. I really want to go to Paama, but when I go, I feel like I don't know where I want to live. I've been living in Vila a long time, but I don't like it. When I go to Paama, I really like it there, but sometimes I struggle, so I think about Vila again. I feel that I need to go and earn money." (Male, 44 years)

Time, access to services and housing, satisfactory employment and the location of close kin all played a part in influencing migration decisions. By 1983 it was evident that urban life in Port Vila offered a number of perceived advantages and, for many, a better quality of life in town, and the availability of diverse economic opportunities (Haberkorn, 1987). Three decades later such 
potential advantages of urban life had increased, even though only some migrants were able to take advantage of them.

\section{Who is returning to Paama? Rationales for return}

While many urban migrants spoke of returning to Paama, actual return migration was limited. Of second-generation migrants who grew up in town, no men and only three women of Paamese heritage had 'returned' to Paama. These women had all relocated after marrying Paamese men whose usual place of residence was the island, and as for return migrants elsewhere in the Pacific (Lockwood, 1990; Maron and Connell, 2008), reintegrating into the rural community required a period of adjustment.

"When I first came [back to Paama] I found it a little bit hard to adjust, I complained. I kept complaining, but my parents spoke to me. They said it was up to me to look after myself and to learn how to adapt to island life ... So I tried my best, and I learned how to live on the island. Now I'm glad to be living here." (Female, 26 years)

Only seven households had returned to Paama after an extended period living in Vila. Six of these had been established in Vila for a period of ten years or more, while the seventh had resided in Vila for roughly six years. At the time of their return, most Paamese households comprised young to middle aged couples with their young children (older children often chose to remain in town). The return of older migrants was uncommon: only two households had 'retired' to Paama after more than twenty years working in Vila. The adults of one of these households continued to make regular trips to Vila to check on children and land, and could be better described as living between the two locations, rather than having returned permanently to Paama. However, this behaviour was uncommon, and while return migration is not always permanent (Maron and Connell, 2008), for most Paamese the social and economic costs associated with relocation meant that remigration was not a feasible option.

Not all return migration to Paama was voluntary. In addition to the households described above, a handful of individuals had returned to Paama due to inappropriate behaviour in town (although there was some overlap between the two categories). Urban residence was considered a privilege, and hence those whose behaviour was not judged worthy of this privilege were sent back to the island by urban kin. Such censorship operated for both males and females: it was whispered that one couple returned from Vila because the wife had become friendly with another man, and several young men had been banished to Paama for smoking marijuana. Censoring mobility was thus considered an effective method for dealing with social problems including adultery, substance abuse and stealing, a strategy not uncommon in Vanuatu (Jolly, 1996; Mitchell, 2004).

Consistent with circumstances elsewhere in the Pacific (Lockwood, 1990; Maron and Connell, 2008), migrants' primary reasons for voluntary return to Paama were diverse and covered caring for kin (2), urban employment ending (2), 'tired of urban life' (2), retirement (1), and to attend to chiefly duties on the island (1). For most households however, return trajectories were not simple, and several factors had contributed to their decision. Significantly, six out of the seven returnee households contained a member with unusual status in the community, including a church elder, store owners (one current, one former), a shipping agent, two chiefs, a kindergarten teacher and a health centre employee. Considering the limited availability of these kinds of role, they were disproportionately represented amongst returnees. The two most recently returned households also owned property in Vila, a testament to their relative economic success. While return migration is not always associated with 'successful' migrants (Tubuna, 1985), taking into account their roles in the community, and access to on and off-island resources including land ownership and small businesses, as for Tongans (Maron and Connell, 2008), voluntary returnees - few in number - were generally 'successful' migrants, with distinctive roles in rural life.

\section{Challenges faced}

For returnees, re-establishing themselves on Paama was rarely easy. Only two households had constructed a house on the island prior to their return. Not having a house to come back to made the process of relocation significantly more challenging, and returnees agreed that unless you prepared yourself, returning to the island was difficult.

"It's really expensive to come back to Paama ... I left Paama in 1973 or 1972. I went to Vila, I stayed a long time and I couldn't come back to Paama anymore. I tell people that they should do what I did. If your husband works, let him keep working. You go to the island first by yourself, and you can pay the community to build you a house ... Once they build the house, you'll have somewhere to live. Your husband can send you food while you're making a garden ... and when you see that there is enough food in the garden to feed your family, you tell them to come. If you prepare things like this, it's easy ... If you want to come back to the island, and everyone comes at the same time, it's hard." (Female, 59 years) 
"Oh, when we wanted to come back, it was hard. We came, but we didn't have a house, we didn't have a kitchen, we came and we had to just sleep with my motherin-law, we all ate together. The day after we came back, my husband started building our house. He worked really hard, and we were able to come and sleep in our own house. We didn't have a kitchen though, which was okay when the weather was good because we could cook outside, but when it rained, we had to go and eat with my mother-in-law. It was like this for a while until my husband could finish making our kitchen." (Female, 45 years)

These accounts were consistent with reasons villagers provided for outmigrants not returning to Paama; invest-

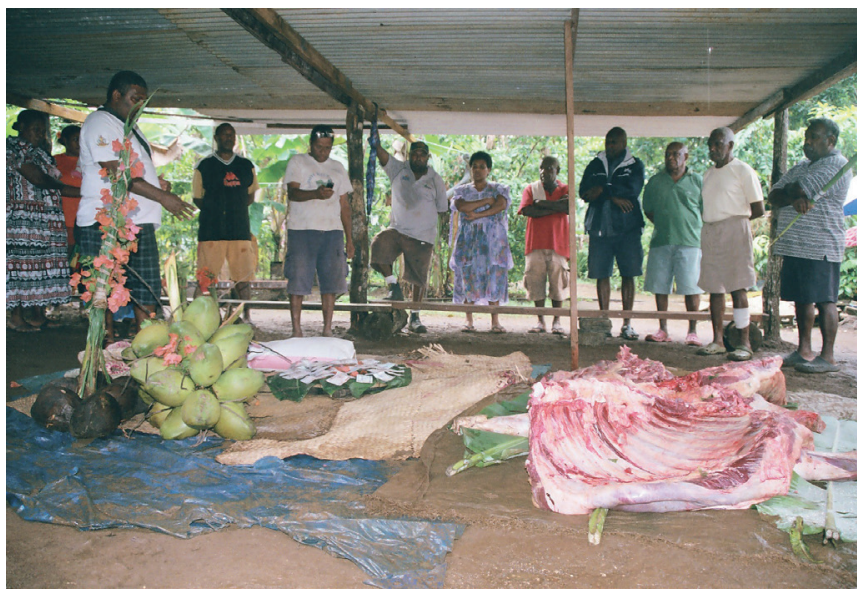

PiCture 1. - Inter-island marriage ceremony, Port Vila, 2011 (C) Kirstie Petrou) ment in off-island land and houses, and holding work elsewhere were considered significant barriers to return, and echoed responses of urban migrants.

"There are plenty of reasons [why people don't come back]. Some of them, you know what it's like when you live in town. You're enjoying life in town, and then you have to come back to the island and start all over again. That's what it's like. If you come back to the island, you don't have a house, so you have to build one. You have to make a garden... You have to do lots of things like this in order to start all over again, in order for you to succeed." (Male, 66 years)

In the face of such challenges, especially for those with formal sector jobs that were simply absent on small islands, established urban lives invariably seemed not unattractive.

\section{The impact of return}

While return migrant households arguably brought development to Paama through their small business activities, there was little difference between the businesses of economically successful return migrants and economically successful non-migrants: both required some form of off-island support, and both were expected to contribute to the community through, for example, donations of food for community fundraising and other events. The status of several of the returnees further contributed to island leadership and service provision.

Return migrants differed from their non-migrant counterparts primarily through their knowledge of the urban Paamese community. While rural Paamese could identify first-generation migrants, and most knew at least the names of second-generation family members, there was little knowledge of migrants who did not maintain close contact with rural Paamese, nor of their children. This was particularly true of migrants who had few immediate family members on the island. With their knowledge of the urban Paamese community therefore, return migrants played an important role in reinforcing the link between rural and urban residents, and in perpetuating the translocal nature of the Paamese community.

While the social capital of return migrants made an important contribution to Paama, there is a limit to how many such households could be comfortably accommodated on the island. As a small island with a large migrant population, there was a recognition by Paamese that while it would be pleasant in theory if everyone could live on Paama, large scale return migration was simply not feasible.

"If one day everyone came back to Paama, the island would be too small. Everyone would fight over land." (Male, 28 years)

It is possible therefore, that Paamese faced greater structural barriers to return than migrants from larger, less densely populated islands. Nonetheless, and as noted above, anecdotal evidence suggests that return migration within Vanuatu (and elsewhere) is limited for migrants across all island groups, and Paamese only rarely cited land concerns as a primary reason for extended urban residence.

Significantly, many urban Paamese held employment in activities for which only one or two rural positions were available (for example nurses, teachers) or did not exist on the island (such as office workers, hospitality workers). Arguably such people made a more useful contribution to the Paamese community by staying in town, and supporting kin through remittances. This was particularly so where their return might jeopardise the livelihoods of rural relatives through, for example, reclaiming houses or land left in the care of others. While it is unlikely that migrants would leave their kin destitute, it is possible 
that such returns would cause strain on existing rural households with limited land acces. Return migrant households did bring benefit to the island community, but there is a low carrying capacity and threshold for the number of such households that could reasonably be accommodated on the island (see also Lockwood, 1990). Significantly none of the returning households contained members who had had to give up highly-skilled employment to return.

\section{Conclusion}

Despite migrants' claims that they will

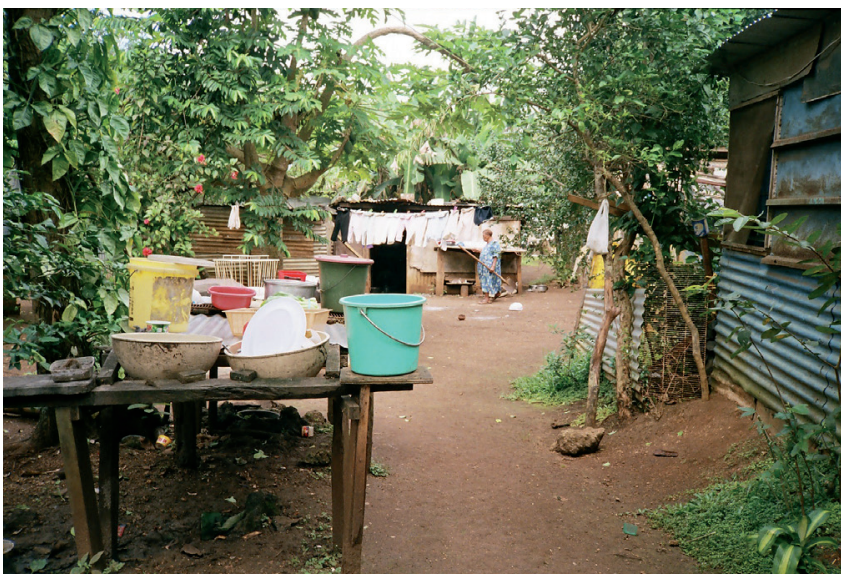

Picture 2. - Typical Paamese housing in Manples urban settlement, Port Vila, 2011 (C) Kirstie Petrou) one day return to their island 'homes', return migration to rural areas of Vanuatu has been limited and minimal in the case of Paama. The persistent discourse of return therefore, can perhaps be best described as a rhetorical device that both expresses nostalgia for an idealised past (see also Lindstrom, 2011), and acts as a means of reinforcing identity and roots (which remain linked to island homes), alongside an expression of concern over urban instability and a claim to rural resources, rather than as a real statement of intent. Indeed, intent may be expressed publicly alongside private doubts (Macpherson, 1985). Ironically an idealised past contrasts with the fear of sorcery discouraging return in Paama and elsewhere (Dalsgaard, 2013). While many Paamese migrants spoke of a desire to return to the 'simple ways' of the island, they had various commitments and goals to achieve beforehand, and had no time frame for such a move. Return was more mythical than real. Importantly, in a context where rural and urban residents are considered part of one continuous translocal community (e.g. Lindstrom, 2011; Thorarensen, 2011; Lind, 2014), and particularly for migrants whose immediate family members reside with them in town, the concept of return migration is not necessarily relevant. Such migrants already actively participate in the Paamese community, not least through remittances, and do not need to 'return' home to be at home. More practically, for many urban migrants the barriers to return were simply too great, and urban permanence had occurred somewhat unintentionally.

While urban permanence is difficult to measure, by 2011 Paamese migrants across all age groups had been living in Port Vila for extended periods. With few exceptions, adults lived in town with their spouses and children. Secondgeneration migrants accounted for a significant proportion of urban residents, and there was general recognition of the increasing difficulties presented by 'return' migration, and the limita- tions, both structural and social, associated with rural existence. Despite earlier predictions (Bedford, 1973; Haberkorn, 1987), the attitudes of first and second-generation migrants to returning 'home' were virtually identical and, despite their often limited experience of rural life, second-generation migrants maintained their Paamese identity through participation in the translocal community. The location of family members was instrumental in influencing return to Paama, while the social incentive to return declined over time. In short, both first and second-generation migrants behaved in a manner that indicated long-term urban commitment, and there was little difference in their attitudes to return. The longer migrants stayed away, the harder it became to return 'home'.

From a rural perspective, the few return migrants were welcomed 'home'. Although making the transition to Paama was difficult, these rather younger and successful households were able to contribute to the rural community through their small business activities and social capital. Nonetheless, the capacity for the rural community to absorb such individuals was limited. Indeed, poverty is easily hidden in outer islands, where there is both a poverty of opportunity, limited livelihoods and restricted access to crucial educational and health resources, employment opportunities and accessible markets. Paama is small and development possibilities are few, while expectations are increasing, hence return migration may well be less than in larger islands, and in other countries. Nonetheless, like everywhere else in the world, the margins are fading, expectations have changed and small islands are less likely to be places to stay or return to. As youths emigrate, numbers fall, services are inadequately provided, incentives to remain decline, and downward spirals enhanced. Cities have become the sometimes reluctant beneficiaries. Not only have later generations made the city their home 


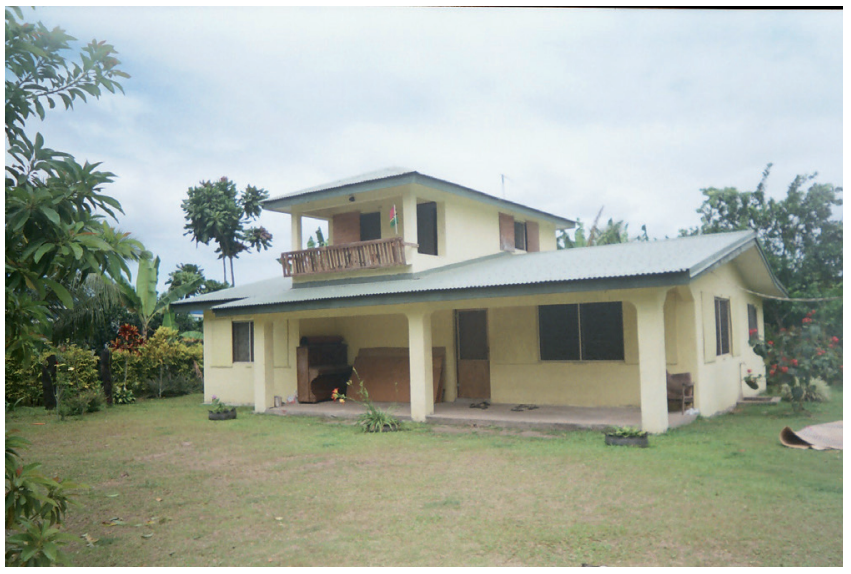

Picture 3. - Building a permanent house in town was considered a symbol of urban commitment, Port Vila, 2011 (C) Kirstie Petrou)

but first generations can also find return more difficult. The kinship safety-nets that enabled return have become overstretched, even when poverty, unemployment, old age or social disorder make urban life difficult. Nonetheless, for Paama at least, first, second and third-generations of migrants are making a positive commitment to a new urban permanence, as the era of circular migration draws to a close.

\section{REFERENCES}

BASTIN Ron, 1985. Weasisi mobility: a committed rural proletariat?, in M. Chapman and R. Mansell Prothero (eds), Circulation in population movement: substance and concepts from the Melanesian case, London, Routledge and Kegan Paul, pp. 175-190.

Bedford Richard, 1973. New Hebridean mobility: a study of circular migration, Canberra, Research School of Pacific Studies, Department of Human Geography, Publication HG/9, Australian National University.

Bonnemaison Joël, 1976. Circular migration and uncontrolled migration in the New Hebrides, South Pacific Bulletin 4, pp. 7-13.

Brown Richard and Connell John, 2015. Remittances and Migration, in J. Connell and R. Brown (eds), Migration and Remittances, Cheltenham, Edward Elgar, pp. XIII-LXVIII.

Chapman Murray and Mansell R. Prothero, 1983. Themes on circulation in the Third World, International Migration Review 17 (4), pp. 597-632.

- (eds), 1985. Circulation in population movement: substance and concepts from the Melanesian case, London, Routledge and Kegan Paul.
Chung Margaret and David Hill, 2002. Urban informal settlements in Vanuatu: challenges for equitable development, Pacific Islands Forum Secretariat and United Nations Economic and Social Commission for Asia and the Pacific, Pacific Operation Centre.

Connell John, 1988. Temporary Townsfolk? Siwai Migrants in Urban Papua New Guinea, Pacific Studies 11 (3), pp. 77-100.

- 2009. 'I never wanted to come home': skilled health workers in the South Pacific, in H. Lee and S. Francis (eds), Migration and Transnationalism: Pacific Perspectives, Canberra, ANu EPress, pp. 159-177.

_, 2011 (August). Elephants in the Pacific? Pacific urbanization and its discontents, Asia Pacific Viewpoint 52 (2), pp. 121-135.

Curry George and Gina Koczberski, 1998. Migration and circulation as a way of life for the Wosera Abelam of Papua New Guinea, Asia Pacific Viewpoint 39 (1), pp. 29-52.

—, 1999. The risks and uncertainties of migration: an exploration of recent trends amongst the Wosera Abelam of Papua New Guinea, Oceania 20 (2), pp. 130-145.

Curtain Richard, 1980. The structure of internal migration in Papua New Guinea, Pacific Viewpoint 21 (1), pp. 42-61.

DalsgaArd Steffen, 2013. The politics of remittance and the role of returning migrants: localising capitalism in Manus province, Papua New Guinea, in F. McCormack and K. Barclay (eds), Engaging with Capitalism: Cases from Oceania, Bingley, Emerald, pp. 277-302.

ERIKSEN Annelin, 2008. Gender, Christianity and change in Vanuatu: an analysis of social movements in North Ambrym, Aldershot, Ashgate.

Gewertz Deborah and Frederick Errington, 1999. Emerging class in Papua New Guinea: the telling of difference, Cambridge, Cambridge University Press.

Haberkorn Gerald, 1987. Port Vila - Transit station or final stop? Recent developments in ni-Vanuatu population mobility, Department of Demography, Canberra, Australian National University, Unpublished PhD thesis.

Jolly Margaret, 1996. "Woman ikat raet long human raet o no?" Women's rights, human rights and domestic violence in Vanuatu, $\mathrm{Fe}$ minist Review 52, pp. 169-190. 
Kraemer Danielle, 2013. Planting roots, making place: an ethnography of young men in Port Vila, Vanuatu, The London School of Economics, London, Unpublished $\mathrm{PhD}$ thesis.

LACito, 2003. The Oceanic Languages: Araki Corpus, retrieved $15^{\text {th }}$ June 2017 from http://lacito. vjf.cnrs.fr/pangloss/languages/Araki_en.htm.

LIND Craig, 2014. Why the future is selfish and could kill: contraception and the future of Paama, in W. Rollason (ed.), Pacific Futures: Projects, Politics and Interests, New York, Berghahn, Volume 2, Pacific Perspectives: Studies of the European Society for Oceanists, pp. 71-95.

Lindstrom Lamont, 2011. Urbane Tannese: Local Perspectives on Settlement Life in Port Vila, Journal de la Société des Océanistes 133, pp. 255-266 (https://jso.revues.org/6461).

Lockwood Victoria, 1990. Development and return migration to rural French Polynesia, International Migration Review 24 (2), pp. 347-371.

Macpherson Cluny, 1985. Public and private views of home: will Western Samoan migrants return? Pacific Viewpoint 26 (2), pp. 242-262.

Maron Nicole and John Connell, 2008. Back to Nukunuku: employment, identity and return migration in Tonga, Asia Pacific Viewpoint 49 (2), pp. 168-184.

Mecartney Sarah, 2001. Blacksands Settlement: a case for urban permanence in Vanuatu, School of Geosciences, Division of Geography, Sydney, University of Sydney, Unpublished Masters thesis.

Mecartney Sarah and John Connell, 2017, Urban Melanesia: The Challenges of Managing Land, Modernity and Tradition, in S. McDonnell, M. Allen and C. Filer (eds), Kastom, Property and Ideology: Land Transformation in $\mathrm{Me}$ lanesia, ANU Press, Canberra, pp. 57-84.

Mitchell Jean, 2002. Roads, restlessness and relationships: an urban settlement in postcolonial Vanuatu, York University, Canada, Department of Social Anthropology, North York, Unpublished PhD thesis.

_, 2004. "Killing time" in a postcolonial town: young people and settlements in Port Vila, Vanuatu, in V. Lockwood (ed.), Globalisation and Cultural Change in the Pacific Islands, New Jersey, Pearson Education, pp. 358-376.

_, 2011. 'Operation Restore Public Hope': youth and the magic of modernity in Vanuatu, Oceania 81 (1), pp. 36-30.
Morauta Louise and Dawn Ryan, 1982. From temporary to permanent townsmen: migrants from the Malalaua District, Papua New Guinea, Oceania 53 (1), pp. 39-55.

Muliaina Tolu, 2003. Remitances, the social system and development in Samoa, in R. Iredale, C. Hawksley and S. Castles (eds), Migration in the Asia-Pacific, Cheltenham, Edward Elgar, pp. 259-272.

OlwIG Karen, 2007. Caribbean Journeys: an ethnography of migration and home in three family networks, USA, Duke University Press.

Philibert Jean-Marc, 1988. Women's work: a case study of proletarianization of peri-urban villagers in Vanuatu, Oceania 58 (3), pp. 161-175.

—, 1994. Nouvelles-hybrides. Journal de la Société des océanistes 99, pp. 197-205 (http:// www.persee.fr/doc/jso_0300-953x_1994_ num_99_2_1937).

Rasmussen Anders, 2015. In the Absence of the Gift: new forms of value and personhood in a Papua New Guinea Community, New York, Berghahn.

Sмiтн Michael, 2002. Village on the Edge: changing times in Papua New Guinea, USA, University of Hawai'i Press.

-, 2013. A Faraway, Familia Place: an anthropologist returns to Papua New Guinea, USA, University of Hawaii i Press.

Strathern Margaret, 1985. The disconcerting tie: attitudes of Hagen migrants towards 'home', in M. Chapman and R. Mansell Prothero (eds), Circulation in population movement: substance and concepts from the Melanesian case, London, Routledge and Kegan Paul, pp. 360-376.

Thorarensen Hildur, 2011. Heal, pray, prosper: practice and discourse within a local Pentecostal church in Vanuatu, Department of Social Anthropology, Bergen, University of Bergen, Unpublished Masters thesis.

Tonkinson Robert, 1979. The paradox of permanency in a resettled New Hebridean Community, Mass Emergencies 4, pp. 105-116.

Tubuna Sakiusa, 1985. Patterns of Fijian return migration in the Wainibuka River valley: Viti Levu, Fiji, in M. Chapman and R. Mansell Prothero (eds), Circulation in Population Movement, London, Routledge and Kegan Paul, pp. 213-224.

Vanuatu National Statistics Office, 2011. 2009 National Population and Housing Census: Basic Tables Report: Volume 1, Port Vila, Goverment of Vanuatu. 